\title{
TEACHING ENGLISH IN ASEANı THE VOICES OF ENGLISH TEACHERS IN ASEAN NATIONS
}

\author{
Peter Waterworth \\ Deakin University, Australia and REAL Project Consultant (UPI and CFBT) \\ pewaterworth@yahoo.com.au
}

First received: 12 August 2015

Final proof received: 22 January 2016

\begin{abstract}
The effective teaching of the English language is regarded as an essential element in the creation of a culturally vibrant, economically sound and socially stable ASEAN community. The ASEAN region is populated by a culturally diverse collection of peoples with very different and complex linguistic histories, some of which included a strong English component. This paper examines the opinions and understandings of teachers of English in eight of the ten ASEAN nations. It arose out of a research study of English teaching in ASEAN being conducted jointly by Universitas Pendidikan Indonesia and CfBT Brunei. Although the teachers differed in their levels of competence in English and in their experience of local, national and international culture, they shared a remarkably similar story in attempting to provide the best instruction they possibly could to their students. As non-native speakers of English, they shared the responsibility of representing not only the English language but also the culture of first language English speakers to their non-native speaking students. The conflicts and tensions of their roles were identified and examined. The study concluded that teachers need support in their intercultural role as well as in their pedagogical responsibilities. Teachers reported that their students had little knowledge or appreciation of the ASEAN community or of the importance of their own capacity to speak English in it.
\end{abstract}

Keywords: ASEAN, teaching English, English as an International Language, Kachruvian circles, English as a lingua franca

\section{English language teaching in ASEAN}

The teaching of English by second language (L2) teachers requires teachers to manage an array of conflicting personal and professional motivations, a deep appreciation of their own national identity, a love for their own mother tongue or first language (L1) as well as a healthy dose of self-reflection. Teachers of English form part of the staff of schools, and, like teachers in other subject areas, face the continuing task of defending the place, prominence and time allocation of their subject. They endlessly promote the importance and usefulness of their subject to their students. In most countries in ASEAN, English forms a compulsory part of the core of the curriculum in both primary and secondary schools. Depending upon the quality of their schooling and teacher training in English, their devotion to learning and to improving their own English skills and their level of self-confidence, teachers may also struggle with doubts about how well they are able to teach English.

The research reported in this paper examines the feelings and opinions of L2 teachers of English throughout eight of the ten ASEAN countries about their roles and responsibilities in teaching English. It attempts to understand their perceived levels of skill and confidence, their goals in teaching English and their linguistic and pedagogical challenges. The research question that was posed was: what are the merits, respectively, of L1 and L2 teachers teaching
English to L2 learners of English within the ASEAN context and what are the consequences in terms of education policy?

ASEAN is made up of ten independent nations in South East Asia (Brunei Darussalam, Cambodia, Indonesia, Lao PDR, Malaysia, Myanmar, Philippines, Singapore, Thailand and Viet Nam) that have determined that they will share in economic and community development. According to Le Luong Minh, Secretary General of ASEAN, English is an important and indispensable tool that will bring the ASEAN community together (ASEAN Secretariat, 2013). English is officially (Association of Southeast Asian Nations, 2008) the only working language of ASEAN, unlike the European Union, which has 23 official languages. The origin of ASEAN is far more recent than the origin of the EU and had been in its developmental stages at the time that English has been more readily accepted as the global language. English became the official lingua franca in 2009, although its unofficial currency was much earlier (Kirkpatrick, 2007). The choice of English had been made in ASEAN "naturally with neither objections nor debates" from any parties (Muttaqin, 2014, 4). ASEAN nations together have more than 1000 languages (400 alone in Indonesia) and great linguistic diversity (Kirkpatrick, 2009). Firth $(1996,240)$ argued that a 'lingua franca' is a language chosen to be the common language of people who do not speak that language as their 
mother tongue. Even though the British colonised as many as four of the countries in ASEAN and had a profound and enduring influence upon other countries in ASEAN, and the US 'colonised' another of the ASEAN countries, English was not considered to be the natural choice of the lingua franca for Asia until the last two to three decades. Using Firth's definition, it could be argued that a lingua franca is a contact language or a working language which had been or could be compromised by the inclusion of a large number of non-standard forms simply because it was used to service the communication needs of a people with vastly different linguistic backgrounds who use it. As Kirkpatrick observed, a lingua franca or chosen common language like English should provide "no necessary linguistic advantages to any speaker" (2009, 3). Where a native speaker of English communicates in English with a non-native speaker, there is a distinct linguistic advantage which could also be construed as a power advantage. Such could not be the case in ASEAN where, to a very great extent, ASEAN citizens do not have English as their mother tongue, although it is interesting to speculate whether such a situation will pertain for very much longer. Kachru (1986) categorised countries that give special emphasis to English into three groups: Inner Circle countries that have English as the national language, Outer Circle countries that were former British or US colonies that use English as a formal language but probably not as a national language and Expanding Circle countries that do not have English as an official language although it may have compulsory status in schools (see also Deerajviset, 2014). Using this grouping, some ASEAN countries are in the Outer Circle (Brunei Darussalam, Malaysia, Myanmar, Singapore and Philippines) and the others in the Expanding Circle (Cambodia, Indonesia, Lao PDR, Thailand and Viet Nam).

English is the most common second language taught throughout ASEAN countries. Apart from Mandarin, there are no second language Asian languages commonly taught in ASEAN countries. The vast majority of teachers of English in ASEAN are second language speakers of English and that proportion is rapidly increasing. In fact, the majority of English teachers globally are L2 speakers of English (Floris, 2013). Much the same applies to the speakers of English. There are far more L2 speakers in the world than L1 speakers of English (Floris, ibid, 47) and almost a decade ago, already one-third of the world's population spoke English (Crystal, 2008)., Moreover, L2 teachers of English in ASEAN must master English, a complex European language totally unrelated to their L1.

In the sociological sense, the learning of the mother tongue is closely intertwined with the process of the socialisation or enculturation of individuals into culture. In a simplistic sense, while a society is a collection of people with a common culture, culture in itself is the product of a society. Our culture envelopes us in every way. Broadly speaking, a culture is a coherent and consistent system which provides us with the means to understand ourselves and to understand and interpret the world around us. Our culture tells us how to behave in various social situations and what to feel and believe about any matter. Our culture provides us with a framework for thinking and valuing and with the methodology for reacting to new things. Our culture provides us with a way to regard ourselves and our role and to create an identity for ourselves in various social or professional contexts.

In fact, it is inaccurate to think of the culture of a society as a monolithic whole. Culture is imagined in a multiplicity of ways depending upon factors of age, sex, ethnicity, social class, social status and location. Some sociologists refuse to employ the term 'culture' and prefer the term 'cultural formation' as a way of emphasising the constant interweaving of factors in forming the social self. The major means by which culture is transmitted is through language - verbal, expressive and visual. The mother tongue we acquire in childhood provides us with far more than just the skills and strategies to use language effectively but also with the accompanying cultural understandings, implications and assumptions of the social group from which it comes. L2 teachers of English must work, think and operate in their teaching of English outside the framework of the culture or subculture of their L1.

\section{The REAL Project}

A project was established in 2014 to Research English as an ASEAN Language (REAL) jointly supported by Universitas Pendidikan Indonesia and CfBT Brunei. The project idea was first formulated by Herli Salim (UPI) and Greg Keaney (CfBT Brunei). The project sought to discover the challenges facing teachers of English in each of the ASEAN countries. It first ascertained responses to a questionnaire from English teachers on a range of issues and opinions on the teaching of English. Fifteen L2 teachers of English were sought from each ASEAN country with responses being gained from all of them except Lao PDR and Singapore (which will be included in a supplementary part of this project). Four teachers who appeared to typify the opinions of other teachers from their countries and who had the best skill levels in English were followed up with an interview. The questionnaire was distributed and responses monitored by a Country Liaison Person in each country. The interview was conducted by members of the Research Team itself in each of the countries included in this project. A total of 108 teacher respondents returned usable questionnaires and of them, 28 teacher respondents were selected for 
interview. The data from the questionnaire is reported elsewhere with a very brief occasional mention here, while the majority of the data reported in this article came from the teacher interviews.

\section{Teaching English}

What motives do L2 teachers of English have in advancing the competence and confidence of their students to speak English? Is their promotion of English capacity in their communities also laying the dubious foundations of the undermining of their communities' national and local languages and cultures? Teachers are forming and challenging their own and their students' sense of themselves by the very act of teaching a foreign language. Wolff (2015) has argued that foreign language teachers' professional, social, political and cultural identities are clearly represented in their teaching practices. Duff \& Uchida $(1997,451)$ argued that, at any one time, "language teachers and students in any setting naturally represent a wide array of social roles and identities." Teachers are being, becoming and representing a series of identities while in the process of teaching (Wolff, op.cit., Beijaard, Meijer \& Verloop, 2004).

Much of the research literature on the teaching of English in non-English speaking countries such as those in ASEAN has focussed on the desired outcomes of English language programs. Common challengeable assumptions have been that the goal of teaching is the achievement of "native speaker competence" in students (Floris, op. cit., 48) and that the best way to achieve that goal is to have English taught by native English speaking teachers (Floris, ibid, Brown, 2012). A large number of contemporary researchers have posited an alternative view that the goal of teaching English in Asia should be to attain the ability to use the language successfully (Kirkpatrick, 2009, Firth \& Wagner, 2007 and Larsen-Freeman, 2007). This debate is highly crucial for policy makers who might be trying to reach some kind of useful view on the teaching of English in ASEAN. The achievement of native-like speech is dependent upon a number of learner characteristics and, according to Kramsch, is profoundly affected by "geography, occupation, age and social status" $(1997,362)$. In any case, some argue that native-like speech is virtually unachievable after childhood (Birdsong, 1992, Felix, 1987) since it is thought that the oral and aural tools of speech may have matured by pre adolescence and would not permit the production of the repertoire of unused sounds long since eliminated in earlier childhood.

Although the evidence is far from convincing, a large number of L2 teachers of English still hold the view that the best teachers of English in Asian settings (and elsewhere) are L1 teachers of English. In interviews of L2 teachers of English conducted by Floris in Indonesia, respondents stated:
In my opinion, the best teachers of English are native speakers of English because they have this language as their mother tongue. They can become the best teachers because they are able to pronounce all words correctly and to explain the grammar rule. Yuni

I believe that the best teacher of English is the native speakers of English (American, British, Australian). Sonia

I believe that the best teachers of English are 'white' people. English is their language so they know it better than any other speakers. Many course advertisements in magazine or in newspaper also claim that they have white people as their language teachers. Setiawan

(Floris, 2013, 66)

Despite their stunning frankness, views like or similar to these are held by many practitioners in schools and training colleges throughout Asia, perhaps mirroring consumer, student or parent preferences. Interestingly, after participating in a short course to raise teachers' levels of selfconfidence, the teachers in Floris's study changed their opinions of their own value as L2 teachers of English (Ibid.). Moussu \& Llurda (2008) concluded that L2 teachers of English are regarded generally as inferior to L1 teachers. Other researchers have reported the strong but, to them, inaccurate perception that L1 teachers of English are the ideal model for language production, demonstrating grammatical correctness, perfect pronunciation and a wealth of valuable cultural knowledge (Braine, 2010, Kirkpatrick, 2010, Lasagabaster \& Sierra, 2005, and Walkinshaw \& Duong, 2014). There are proportionately far more L2 than L1 teachers of English worldwide so the preference for L1 teachers by some is a largely futile one. Just as there are varieties in English within Inner Circle (Kachru, 1986) countries, the varieties of English in ASEAN are also highly diverse (Low \& Hashim, 2012, Prescott, 2007). English is continuously developing and its development is no longer controlled by the Inner Circle. Rather, the locus of its development in ASEAN is non-native with "local or individual contexts with unique identities" (Deerajviset, 2014, 47). Many now suggest that English has become far more complex in a sociolinguistic sense than other languages in the world today (Saraceni, 2009, Sharifian, 2009, Marlina, 2014). The debates on the unwarranted dominance of English internationally as hegemonic or imperialist (Philipson, 2008) or the accusation that discrimination between L1 and L2 teachers on the basis of accent is somehow racist (Amin, 2001, 2004) are perhaps becoming outmoded.

On the other hand, a number of researchers and commentators have provided good evidence that L2 teachers of English may provide particular advantages to their students which L1 teachers 
cannot. Because they may draw upon greater linguistic and metalinguistic experience, Ellis (2004) argued that they provided their students with a deeper understanding of the L2 being studied. Kirkpatrick $(2009,13)$ argued that regional or local L2 teachers provide a "more appropriate linguistic model" than a native English speaking teacher. Other researchers have shown that L2 language teachers tend to place better emphasis upon better pedagogy (perhaps because a large number of L1 teachers teaching in Asia may not be as well qualified in teaching methodology), to provide better grammatical teaching and to have a better understanding of their L2 learners (Liang, 2002, Mahboob, 2003, Benke \& Medgyes, 2005, Pacek, 2005 and Cheung \& Braine, 2007).

In considering the relative merits of L1 and L2 English language teachers, Walkinshaw \& Duong (2014, 7ff) concluded that each group of teachers had different characteristics to offer learners based largely on their prior experiences of learning and using language. Even the generalisation of characteristics of this kind by group needs to be questioned. L1 teachers may have, in general, had more authentic, natural pronunciation, though they may have not been so strong in explaining grammar or in understanding the struggles of their L2 learners. Conversely, L2 teachers while being less fluent, could use the L1 of learners to enhance and broaden the understanding of more complex concepts. Walkinshaw and Duong (ibid) suggested that a combination of various kinds of teachers with a multiplicity of language experiences and training might be best for L2 learners.

\section{Challenges facing L2 teachers of English in ASEAN}

Data in this project were drawn from L2 teachers of English in eight ASEAN countries $(\mathrm{N}=108)$ of which about one quarter $(\mathrm{N}=28)$ were interviewed by members of the REAL Research Team from UPI and CfBT. Interviewers followed the same research protocols and interview schedule and interviewed participants in English in the participants' own localities or schools. The participants were selected according to the measure by which they typified L2 teachers of English in their country across primary, junior secondary and senior secondary schools. The levels of English competence of the participants varied tremendously across the region and, although the sample was not selected randomly, and unevenness was apparent which may approximate the levels of competence in actuality as is shown in Figure 1.

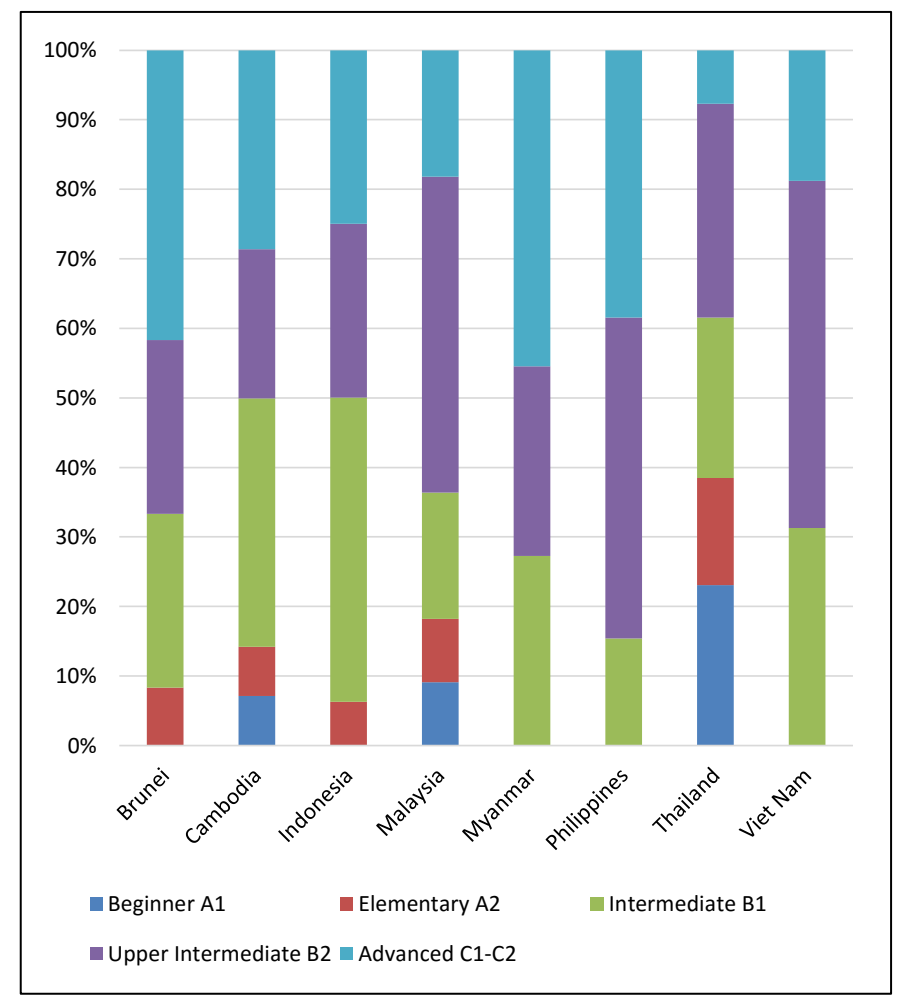

Figure 1. Sample - Level of Teachers' English Competence $(\mathrm{N}=106)$

Participants from Philippines, Brunei Darussalam and Myanmar had the higher levels of skill in English while those from Thailand, Indonesia and Cambodia had the lower levels. These levels may have reflected the influence of British colonial presence or otherwise in the history of the countries concerned or Outer and Expanding Circle statuses (Kachru, 1986). Such a factor may have some relevance for the linguistic advantage that countries take into the ASEAN community. Had 
data from Singapore or Lao been included here, the differentiation may have been more marked.

What levels of confidence did teachers have about their ability to speak English? Did they feel they needed further study in English and did they enjoy teaching English? Figure 2 shows that teachers, in general, felt confident communicating in English with Brunei Darussalam and Philippines at the top and Thailand and Vietnam at the lower end of the scale again reinforcing the Outer and Expanding Circle dichotomy (Kachru, 1986). Teachers in all countries felt the strong need to study English further, with Indonesian teachers feeling the strongest need. Teachers from all countries strongly affirmed that they loved teaching English despite the other considerations about confidence in speaking English.

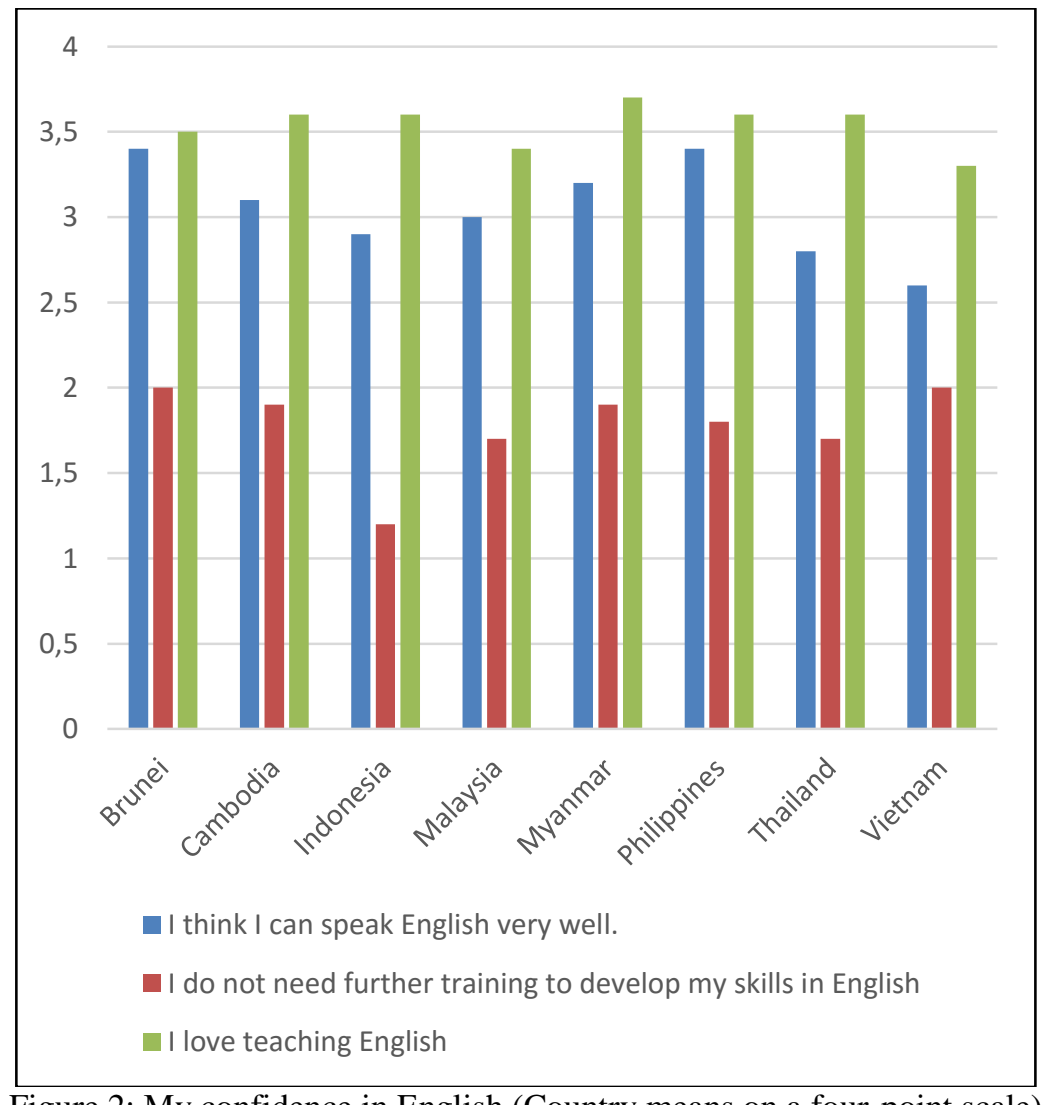

Figure 2: My confidence in English (Country means on a four-point scale)

\section{Teaching English in ASEAN}

L2 teachers of English in ASEAN countries have a critical responsibility in teaching the lingua franca of the ASEAN community whether they realise it or not. They are providing access for their students to the region as well as to the international community. Their voices articulate their certainties, fears, confidence, self-doubt, unfounded assumptions, inaccuracies, ambitions and frustrations.

We wanted teachers to consider the wider implications of their teaching of English something they may not have commonly done. We were hoping that they would describe the national consequences of their roles so we asked: what impact will the learning of English have upon your country? These were typical responses.

I think learning English will always have a good impact upon my country's future, because it will give our people ability or competence to communicate with other people all over the world, since English is an international language. This will open so many opportunities to our people to develop our country, and to increase our welfare. Dian S, M, 48, Junior Secondary, Intermediate B1, Indonesia

We all know that the world is now like a village with the internet and English is the key to accessing this information. We need to be able to use English to tell others about our country.

Thi W, F, 37, Primary, Advanced C1-2, Myanmar

I believe there will be bad impacts if we do not seriously teach Thai people English. They will be left behind and outrun by other countries which are good at English. By learning English, Thai people will be able to keep up.

Prija B, F, 29, Primary, Intermediate B1,

Thailand

Teachers all thought that English was an indispensable necessity for the future and that it would have a very positive impact upon their 
countries. A number of ideas about the necessity of English appeared more than once in these few remarks including an expansion of communication opportunities internationally, superior national development and the provision of a better way of life. The teachers could appreciate the dramatic national implications of the teaching of English.

\section{Competence and confidence in learning and teaching English}

Teacher participants demonstrated a great deal of skill in the performance of their duties but still struggled with self-doubt and a sense of inferiority in their own English language skills. They constantly reflected on what they perceived to be the superior skills of L1 teachers of English and repeatedly demanded the accuracy of L1 speakers of English in their students. Teachers were asked to describe the factors that make their teaching of English easier. We felt that this question would elicit factors that would help to improve competence in English for themselves as well as their students.

The problem is that students' lack of pronunciation knowledge. Another problem is the high number of students per class (about $35-40$ students). Besides, the textbooks are also not diversified or quite expensive, so students can't practice as they should.

Hai T, F, 26, Primary, Viet Nam

They are more willing to write in English, probably because they don't have to speak in front of their classmates, there isn't that shyness factor. It's only me reading their papers. Some are even shy about showing others their written work. I teach both boys and girls, the size for English is 35 students. That's small compared to my grade school. In public school there can be 70 students in class.

Gerna E, F, 30, Junior Secondary, Upper Intermediate B2, Philippines

In order to teach English effectively we have to try hard especially with preparing the lessons. You have to spend a lot of time on making lesson plans. Sometimes I feel like I'm not qualified to be an English teacher.

Nanda H, F, 46, Junior Secondary, Upper Intermediate B2, Myanmar

Well, right now my main concern with my students is their level of vocabulary is low, so they are using the same words over and over. They know how to read and write, but to make the writing more interesting and in the oral exams they need a wider range of vocabulary. I want to start an extra class to focus on vocabulary.

Siti M, F, 36, Secondary, Advanced C1-2, Brunei Darussalam

Listening and pronunciation skills need to be developed. Words have to be very carefully pronounced when being introduced.
Marla T, F, 43, Senior Secondary, Advanced

C1-2, Myanmar

I should have access to internet easily at school that I use for increasing my English knowledge. I can learn via internet and get in touch with my students as well as I can download the material. To me, being easy for internet is very essential at this time.

Tika H, F, 60, Primary, Upper Intermediate B2, Indonesia

First, I think it's due to students' attitudes. The student will learn English better if they are motivated, but in my experiences, mostly students have bad attitudes towards English. They think English is difficult, therefore they do not pay much attention to when learning English. Second, they have less contexts of English use. The students are not supported by contextual use of English outside the classroom, which is why they often easily forget, as they do not have chances to practice English besides school. Third, the curriculum is also problematic, especially in primary level. We only teach English once in a week, only for 50 to 60 minutes. In my opinion, this is way too short to build a foundation of English to primary learners. Prija B, F, 29, Primary, Intermediate B1, Thailand

Interestingly, teachers focussed particularly upon their own perceived weaknesses as teachers of English including lack of sufficient qualifications (Nanda), not knowing what is needed in lessons (Nanda) and the 'essential' need to increase English knowledge (Tika). Teachers mentioned a number of common factors as needs of their students. Chief among these was the need for students to have more accurate pronunciation, confidence in speaking and the capacity to use English within natural contexts. This was followed by the need to improve accuracy in written English and listening skills. These opinions raise the question of whether these L2 teachers were mirroring the opinion that the purpose of a good English language program was to produce students with native speaker accuracy (Birdsong, 1992, Felix, 1987, Floris, 2013). Perhaps this is reading too much into the data since, in any event, most teachers in any subject area seek the highest levels of accuracy in their students. Further, it may be possible that the teachers were projecting their own feelings of inadequacy in English on to their students.

\section{Goals in teaching English}

We wanted the teachers to give opinions on the impact - negative and positive - of English upon their students and communities. This helped us to discover what they thought were the goals or intentions they had in teaching it.

The people who learn English, they will know more about the world, they will know how to make 
their life easier, they will reach to the goal that they want by using English language.

Ollie D, F, Intermediate B1, Cambodia

Many of the ethnic minorities in Myanmar who don't have Burmese as their L1 don't want to study in English. Most of the students though would like to study abroad and take part in exchange programmes so there is a view that English should be a compulsory subject in the school curriculum. The majority really want to study English.

Even though we were a British colony most people don't feel that learning English is a negative thing. General Aung San was determined to study English so that as the leader of the country he set an example for young people in terms of learning language skills. It's a positive change that we can speak in English. Many young people now communicate in English. Some people are worried that the Myanmar language will vanish but us educators realise that we need to use grammatically correct Myanmar and grammatically correct English - so both still need to be taught. Personally I feel that people enjoy learning languages - many can speak 5 or 6 .

Marla T, F, 43, Senior Secondary, Advanced

C1-2, Myanmar

What matters the most is students' level of motivation. Previously my students at secondary, are not motivated enough, and there is lack of support from home, no one is speaking English at home. Even though they are surrounded by English in media, music, it's not academic language. So you get this colloquial language in their compositions. They don't read a lot, and have limited access to books. The school has some, but not a wide range of reading materials. There is a restricted range of books available in schools as books are audited for MIB. They don't really read newspapers unless you force them. A small minority take their own initiative though.

Madihah A, F, 36, Senior Secondary, Upper Intermediate B2, Brunei Darussalam

I think it's a win-win situation for us. Because the Filipino language is already there, so we need to harness our skills at learning that language. The learning of English does not hinder or hamper the learning of Filipino, or other dialects. In fact there are more advantages from learning and studying the English language. Like I said there are more opportunities to work abroad, to serve other people in different parts of the world.

Banoy S, M, 32, Primary, Advanced C1-2, Philippines

We face many problems in teaching English effectively. Learning media, facilities... But the most is problems caused by cultural perception. Our local "minor" culture tends to avoid accepting all things from the west.

Dian S, M, 48, Junior Secondary, Intermediate B1, Indonesia

Their most common response was that they taught English to increase students' awareness of the world (Ollie, Madihah and Dian), to give them a broader understanding and appreciation of the importance of languages (Madihah, Banoy and Marla), to aid students in seeking overseas study or exchange opportunities (Marla and Banoy) and to make students aware of the opportunities and benefits of English as a world language (Marla and Madihah). According to Clyne \& Sharifian (2008), English bestows particular benefits upon L2 learners of it. Dian's comment summed up these views more broadly when he said that accepting English was regarded as being tantamount to "accepting all things from the west". This is a somewhat troubling remark which likens the learning of English to rejecting the local or national cultural formations while embracing the cultural formations of the west. Is it reverting to the old colonial paradigm where English or European cultural formations are regarded as somehow superior to non-European ones?

\section{Interference between mother tongue (L1) and English (L2) in learning}

We wanted to hear the opinions of the teachers on the relationship between their local or national languages and L2 English. What were the pedagogical, linguistic or cultural issues they faced in teaching English? How did they juggle nationality and linguistic issues in their teaching?

The students refusing to learn English and secondly, L1 interference.

Aishah A, F, 34, Junior Secondary, Malaysia

Since the focus of learning English in most of schools in Viet Nam is grammar, it becomes difficult to teach them higher English communication skills in higher education. It is difficult to ask the students to communicate in English because of the grammar-centered learning used since primary school.

$\mathrm{Nu}$ T, F, 28, University, Viet Nam

They aren't that well versed in English yet. They do code switching, so I must speak more slowly in English. They are more used to Filipino coming from public school. At first I thought I shouldn't do code switching (switching between English and Tagalog) but I realized they needed me to help them. So first I say it in English, then in Filipino then I make them say it in English. In class they can understand the question, but they don't know how to express themselves in English. So I let them say it in Filipino first, and then I'll help them translate that in English. When we do exercises or write, it usually takes the whole period to do that translating. They ask me, "Miss, what's the English word for..." And of course there are words with multiple meanings, so it gets confusing. I'm teaching them in the first level. They know words, but if they need to construct sentences, they find it hard to translate phrases into English.

Gerna E, F, 30, Junior Secondary, Upper Intermediate B2, Philippines 
As students get better in English, they are even thinking in English. When we ask them to speak in Malay, even the Malay teachers agree, the level of Malay is getting worse. (What is being done about that?) I know the government is having competitions, trying to encourage Malay, patriotic songs, any competitions are increased, in and out of schools. Before it seemed all of the activities and competitions were in English, but now it seems there is more in Malay, trying to have a balance. About Malay literature, in my school the Malay literature is only offered to arts, or lower level classes, not the higher level science stream classes. And to understand literature you need a higher level of thinking, so it's a very difficult subject.

Siti M, F, 36, Secondary, Advanced C1-2, Brunei Darussalam

Hmm ... there are many other reasons why Bahasa Melayu is deteriorating. Using English might be one of the reasons but not the major reason. I am still Malaysian no matter what language I use.

Zati B, F, 35, Senior Secondary, Intermediate B1, Malaysia

The Myanmar language cannot be spoiled by using English a lot. On the other hand I'm a little bit worried for my students because when I grew up we learnt both languages. My students only learn English at our school and some students look down on the Myanmar language so I'm so worried about some of the next generation of students. Some students are not willing to learn the Myanmar language as it's difficult to write and it takes a long time to learn the Myanmar spellings. Maybe this is only a problem for international schools like mine. In government schools they learn both Myanmar and English.

Thi W, F, 37, Primary, Advanced C1-2, Myanmar

The learning of English does not hinder or hamper the learning of Filipino, or other dialects. In fact there are more advantages from learning and studying the English language.

Banoy S, M, 32, Primary, Advanced C1-2,

Philippines

It's good because Vietnamese people can use it to introduce and inspire friends abroad to learn more about Viet Nam, especially our language. It's bad when people around us are talking English at work and getting used to using it in daily life, they would miss the spirit of Vietnamese or forget how to use it properly to express their feelings or ideas to those who just speak Vietnamese.

Hai T, F, 26, Primary, Viet Nam

While some mentioned the rejection of English by some of their students ('refusing to learn' Aishah) others attempted to use a range of strategies like 'code-switching' (Gerna). Some held the view that parallel teaching of L1 and L2 with equal rigour was essential. Opinions of teachers on the balance between L1 and L2 in schools were most revealing. A number stated that the L1 or national language was under threat by the increase in use of English by students. For example, Siti said 'the level of Malay is getting worse', Zati that 'Bahasa Melayu is deteriorating', Thi that 'some students look down on the Myanmar language' and Hai that 'they ... miss the spirit of Vietnamese or forget how to use it properly to express their feelings or ideas to those who just speak Vietnamese'. However, in contrast, Banoy said 'The learning of English does not hinder or hamper the learning of Filipino'. Some felt more concerned about the loss of the mother tongue in private schools (Gerna) or English-only schools (Thi). There was also concern expressed about the teaching of English or of L1 at higher levels $(\mathrm{Nu}$, Siti and Gerna) because of the incapacity of teachers to cope or the inadequacies of curriculum materials.

A couple of statements by teachers stood out because of their clarity and precision. Zati from Malaysia captured the notion of the independence of the concept of national identity irrespective of language when she said 'I am still Malaysian no matter what language I use'. Then Banoy from the Philippines reinforced the idea of the linguistic advantages of learning L1 and L2 in concert with each other by saying 'the learning of English does not hinder or hamper the learning of Filipino, or other dialects. In fact there are more advantages from learning and studying the English language'.

\section{ASEAN and English}

Most teachers in our sample had not thought much about ASEAN, or even the fact that the selection of English as the working language ASEAN might have an impact upon the teaching of English in the region. Our questionnaire may have raised previously unconsidered questions and the interview gave us the chance of exploring their understanding of ASEAN further. We were interested in finding out how the ASEAN community might encourage cooperation between teachers in the teaching of English throughout the region.

English language in Brunei is not just the second language, in my area it's the third or fourth. Even when we try to teach the standard Malay, it's very difficult. It's the exposure. Some children only learn English in the classroom, not outside. There's no support from the family, they speak in their dialect. Even though they watch television, it's not always in English. So to give them exposure in this, it's up to us the teachers.

Kurnia A, M, 46, Primary, Upper Intermediate B2, Brunei Darussalam

The youth know very little about ASEAN, and the role that Brunei has to play. With only ten countries, every country must contribute a lot. We are quite blessed here, access to education and quite well off as well. So I think because of 
that, we need to share with the other countries, our knowledge. In my program, one of the objectives was to improve the teaching capacity in the developing countries of ASEAN...For me, the main issue is to educate young Bruneians about the role we can play and to help other countries. But for us, English would not be a problem and we can take the lead and share our resources with other counties.

Madihah A, F, 36, Senior Secondary,

Upper Intermediate B2, Brunei Darussalam

When I attended a seminar on the ASEAN language, it showed the ASEAN flags are linked. I feel it's a tool that will help the countries communicate without the national language being set aside.

Maya L, F, Junior Secondary, Advanced C1-2, Philippines

Private schools are doing well, are fine, but if English is the ASEAN language, we need to give more time and resources available for English for all students... I think the Philippines has a lot of potential in learning English, we used to be the number one English speakers in Asia.

Gerna E, F, 30, Junior Secondary, Upper Intermediate B2, Philippines

Thailand may face problems in terms of human resources. The people here are still short of quality in using English. Besides, the GDP is also still considered low. Thai people also lack knowledge about ASEAN.

Phloi P, F, 52, Senior Secondary, Upper Intermediate B2, Thailand

These respondents suggested that an increased and increasing focus on English in this multi-linguistic community would probably have a detrimental effect upon the teaching of L1 languages in the region in the future. Some researchers would concur, arguing that today's users of English are predominantly bilingual or multilingual users of English (Crystal, 1997, McKay, 2012, McKay \& Bokhorst-Heng, 2008, Graddol, 1999, Marlina, 2014) but may not accept that such a characteristic was necessarily detrimental to local or national languages. The respondents believed that the countries in ASEAN were unequal in the knowledge their people had of English (Madihah, Gerna and Phloi), in the educational opportunities they offered in English to their communities (Madihah), in their financial resources which could be allocated to English teaching (Madihah and Phloi) and in knowledge of or access to better pedagogical strategies to improve English language teaching (Madihah). There was a need for more time for English lessons as well as better teaching resources (Maya and Phloi).The opportunities to learn English should be made equally available to all students across the community - not just to those in senior years, in selective schools and private schools.
Such an opinion was in accord with the ASEAN declared principles of equality of access (ASEAN Secretariat, 2009)

It was heartening to have strong endorsement of the idea of mutual support between the ASEAN nations in the teaching of English (Madihah, Maya and Gerna). It was suggested that those countries with better resourced programs could offer support to other countries in the region. Some teachers in our sample had already been to other ASEAN countries to conduct in-service training in the teaching of English. This feeling of mutuality reinforced the express aims of ASEAN (Association of Southeast Asian Nations, 2012). However, it also reinforced the Outer and Expanding Circle categorisation of Kachru (1986).

Teachers stated that students were largely unaware of the introduction of the ASEAN community and the implication that may have had for them, the students, in the future. They considered that it would be worthwhile for teachers of English to present lessons on ASEAN in English (Madihah and Phloi).

\section{DISCUSSION}

This study listened to the voices of L2 teachers of English in eight of the ten ASEAN nations to ascertain how they imagined and fulfilled their role in primary, junior secondary and senior secondary schools. It sought to understand their experiences and opinions on a number of contestable issues in language teaching in relation to the oncoming age of ASEAN.

The language and culture we first learn (L1) define and determine our place and our identity. They create our sense of ourselves, our feelings, opinions and values. Learning a new language (L2) provides us with the opportunity to expand our horizons, to understand a little of speakers of that language and to gain a better sense of ourselves and our own world. Language conveys and expresses culture and positions our culture in relation to other cultures. L2 teachers of English bear the burden of both their own culture and that of the English speaking world, whether they know it or not. Within ASEAN, L2 teachers of English are not only agents or facilitators of change within their own communities, they are also unwitting ambassadors of the English speaking world (not necessarily 'the west') and of internationalism. There are different levels of competence of English teachers throughout the ASEAN community and these may be attributable largely to the different experiences of contact with English. The most telling difference appeared to be between ASEAN countries within the Outer Circle (Brunei, Malaysia, Myanmar, Philippines and Singapore) and the Expanding Circle (Cambodia, Indonesia, Lao PDR, Thailand and Viet Nam). 
There was good evidence from this study that teachers of English in the more favoured areas were willing to share ideas and resources with those in greater material or pedagogical need.

Teachers in this study were convinced about the benefits of a good quality English language program in their countries to assist their students to acquire an increased knowledge of the world, to accelerate their capacity to participate in that world and to grasp the opportunities offered by that world. Competence in English opened the doors of opportunity and increased life chances. Even though they did not want to see the diminution or dilution of the local or national languages in their country they believed that a greater capacity to speak English would assure their countries greater economic power, political prominence and respect. At the same time they considered that their national languages afforded the same power, prominence and respect to their nations within the region. National pride was a key and abiding factor in their consciousness. In addition, some teachers believed that a good knowledge of English reduced the amount of concern they had for the loss of the national or local languages, that it enhanced the learning of multiple languages and that it provided a useful vehicle for explanations of their own culture to foreigners. Sharifian (2011) argued that English was a vehicle for users to project their cultural identities and to express their cultural conceptualisations.

Teachers in most ASEAN nations were concerned about the lack of resources and support for the adequate teaching of English. They were concerned about big class sizes (especially in the government sector), teachers with low levels of English proficiency, the lack of an adequately constructed English language curricula and the cultural challenges to teachers as facilitators of English culture. These views have been corroborated in other research (see for example Muttaqin, 2014, Yuwono \& Harbon, 2010).

The debate about the capacity of L2 teachers of English to teach the subject adequately (as against L1 teachers) proved contentious in this study. Where teachers reflected on this issue, most expressed a feeling of inferiority in terms of language accuracy, pronunciation and accent and knowledge of the culture of English speaking peoples. There was an unspoken belief that L2 teachers struggled in the perception of their levels of competence when compared to L1 teachers of English. This was a revealing outcome of this study since the confidence of teachers in their knowledge of English and in their teaching of it is vital to successful programs in English in schools. The fact is, that there are many times more L2 teachers of English in ASEAN than L1.

Underlying this debate was the question of the goals for the study of English in schools. Some of the literature on this question maintained that grammatical and pronunciation accuracy was a key objective. The goal of programs in English, it was maintained, should be the capacity of students to speak with native speaker accuracy. Many of the teachers in this sample shared this view. Other researchers held the view that competence in communication should not be measured solely on the basis of standard English. In ASEAN, as in Inner Circle countries, there are many varieties of English. In a lingua franca language, so it was argued, non-standard grammatical features as well as a variety of accents should be acceptable. The teachers interviewed in this project were more likely to hold to the older paradigm, seeking correctness and accuracy in their students (and maybe also themselves). This was in contrast to the more contemporary position amongst researchers, that regional accents, vocabulary, grammatical forms and phrases should be encouraged in ASEAN classrooms. Some have suggested that it is essential not to teach EFL students only one single English accent or model (Moussu \& Llurda, 2008, Jenkins, 2007). These arguments have led to the serious proposition (and a prolific literature) that English should be taught as a heterogeneous language with a variety of grammars, vocabularies, accents and patterns of speech (Alsagoff et al., 2012, Kirkpatrick \& Sussex, 2012, Zacharias \& Manara, 2013). These courses in English should also include the promotion of intercultural competence, awareness of the variety of English, multilingual classroom discourse and materials that contain both locally and internationally sensitive examples (McKay, 2012).

\section{CONCLUSION}

The learning of English is an essential element in the success of the ASEAN community. Through English, it will be possible for the citizens of ASEAN (and not just their leaders) to have an equal capacity to communicate throughout the region, to conduct business and negotiate, to engage in the professions and to share equally in joint regional activities and enterprises. Second language English teachers dominate the English language classrooms in the region with a large and significant role in educating the future communities of the region to speak English with confidence and fluency; ASEAN depends on them. Is the model of teaching they use suitable for their teaching responsibilities? Does the English they speak permit their students to learn adequately so that they may converse across cultures to other speakers of English? Do their curricula guide them to teach the necessary concepts? And does their initial training and subsequent professional development permit them to use effective teaching strategies in a confident manner? 
English is a constantly evolving language with its evolution accelerating dramatically in the last two decades as the language has penetrated into newer and ever expanding regions. The model or 'gold standard' British or American English can no longer hold the monopoly in mode or form throughout the world since linguistic diversity has led to the inclusion of a multiplicity of non-standard local, national and ethnic features that cannot be controlled or coordinated. ASEAN contains many Englishes and as ASEAN communities work together using English, newer features of the English language will emerge that may be unique to ASEAN or to parts of ASEAN. The willingness to work cooperatively on the spread of English throughout the region will be a key to the success of the ASEAN enterprise.

\section{Acknowledgement}

The support of the Rektor of Universitas Pendidikan Indonesia (UPI), Prof Furqon, MA, PhD, to this project is gratefully acknowledged. The contributions of Dr Herli Salim (REAL Research Director, UPI) and Dr Greg Keaney (Country Manager, CfBT Brunei) are acknowledged in reading and commenting on earlier drafts of this paper. The author gratefully acknowledges grants for the funding of the REAL project from UPI and CfBT Brunei. Also on the REAL research team were Dr Wachyu Sundayana and Sudarsono (UPI) and Dave Laming, Allison Rajab and Jean Kiekopf (CfBT Brunei). The REAL Project was conducted with the generous assistance and advice of Country Liaison Persons in each of the ASEAN countries selected for the study, namely, Robyn Elmi (Brunei Darussalam), Thearith Bun (Cambodia), Dr Herli Salim and Sudarsono (Indonesia), Pauline Lee (Malaysia), Andrea Phillip (Myanmar), Melinda Lamorena (Philippines), Dr Niratchakorn Thongnoi (Thailand) and Hoa Thi Thanh (Viet Nam).

\section{REFERENCES}

Alsagoff, L., McKay, S.L., Hu G., \& Renandya W.A. (Eds.), (2012) Principles and practices for teaching English as an international language. Bristol: Multilingual Matters.

Amin, N. (2001). Nativism, the native speaker construct, and minority immigrant women teachers of English as a second language. The CATESOL Journal 13(1), pp. 89-107.

Amin, N. (2004). Nativism, the native speaker construct, and minority immigrant women teachers of English as a second language. In L.D. Kamhi-Stein (Ed.), Learning and teaching from experience: Perspectives on non-native English-speaking professionals (pp. 61-90). Ann Arbor: University of Michigan Press.
ASEAN Secretariat. (2009). ASEAN Economic Community blueprint. Jakarta: ASEAN Secretariat.

ASEAN Secretariat (2013). Secretary General: English is indispensable to ASEAN Community. Address given at the Global Conference on Educating the Next Generation of Workforce: ASEAN Perspectives on Innovation, Integration and English, Bangkok, June. ASEAN Secretariat, Jakarta. Retrieved on 29-11-2013 from

http://www.asean.org/news/asean-secretariatnews/item/asean-sg-english-is-indispensableto-asean-community

Association of Southeast Asian Nations, (2008). The ASEAN Charter. Retrieved on 25-7-2015 from http://www.aseansec.org/translations-of-theasean-charter/

Association of Southeast Asian Nations. (2012). ASEAN Overview. Retrieved on 25-7-2015 from http://www.asean.org/asean/aboutasean/overview/

Beijaard, D., Meijer, P.C., \& Verloop, N. (2004). Reconsidering research on teachers' professional identity. Teaching and Teacher Education, 20, pp. 107-128.

Benke, E., \& Medgyes, P. (2005). Differences in teaching behavior between native and nonnative speaker teachers: As seen by the learners. In E. Llurda (Ed.), Nonnative language teachers: Perceptions, challenges and contributions to the profession (pp. 195215). New York: Springer.

Birdsong, D. (1992). Ultimate attainment in second language acquisition. Language, 68, pp. 706755.

Braine, G. (2010). Nonnative speaker English language teaching: Research, pedagogy and professional growth. New York: Routledge.

Brown, J.D. (2012). EIL curriculum development. In L.Alsagoff, S.L. McKay, G. Hu, \& W.A. Renandya (Eds.), Principles and practices for teaching English as an international language (pp. 147-167). Bristol: Multilingual Matters.

Cheung, Y.L., \& Braine, G. (2007). The attitudes of university students towards non-native speaker English teachers in Hong Kong. RELC Journal, 38, pp. 257-277.

Clyne, M., \& Sharifian, F. (2008). English as an international language: Challenges and possibilities. Australian Review of Applied Linguistics, 31(3), pp. 1-16.

Crystal, D. (1997). English as a global language. Cambridge: Cambridge University Press.

Crystal, D. (2008). Two thousand million? English Today 24(1), pp. 3-6.

Deerajviset, P. (2014). The ASEAN Community 2015 and English language teaching in Thailand. Retrieved on 25-7-2015 from 
http://human.pn.psu.ac.th/ojs/index.php/eJHUS O/article/viewFile/147/151

Duff, P.A., \& Uchida, Y. (1997). The negotiation of teachers' sociocultural identities and practices in post-secondary EFL classrooms. TESOL Quarterly, 31(3), pp. 451-486.

Ellis, E.M. (2004). The invisible multilingual teacher: The contribution of language background to Australian ESL teachers' professional knowledge and beliefs. International Journal of Multilingualism, 1(2). Pp. 90-108.

Felix, S.W. (1987). Cognition and language growth. Dordrecht, Netherlands: Foris.

Firth, A. (1996). The discursive accomplishment of normality: On 'lingua franca' English and conversation analysis. Journal of Pragmatics 26, pp. 237-259.

Firth, A. \& Wagner, J. (2007). Second/foreign language learning as a social accomplishment: Elaborations on a reconceptualised SLA. The Modern Language Journal 91(1), pp. 285-300.

Floris, F. D. (2013). Exploring beliefs of pre-service teachers toward English as an international language. ThaiTESOL Journal 1(1), pp. 46-75.

Graddol, D. (1999). The decline of the native speaker. AILA Review, 13, pp. 57-68.

Jenkins, J. (2007). English as a lingua franca: Attitude and identity. Oxford: Oxford University Press.

Kachru, B.B. (1986). The alchemy of English. Oxford: Pergamon Press.

Kirkpatrick, A. (2007). World Englishes: Implications for international communication and English language teaching. Cambridge: Cambridge University Press.

Kirkpatrick, A. (2009). English as an Asian lingua franca and the multilingual model of ELT. Paper presented at the Hong Kong Association of Applied Linguistics Research Forum, Hong Kong Polytechnic University, Hong Kong, December, 1-18.

Kirkpatrick, A. (2010). English as a lingua franca in ASEAN: A multilingual model. Hong Kong: Hong Kong University Press.

Kirkpatrick, A. \& Sussex, R. (2012). English as an international language in Asia: Implications for language education. New York: Springer.

Kramsch, C. (1997). The privilege of the non-native speaker. Publications of the Modern Language Association of America. 112, pp. 359-369.

Larsen-Freeman, D. (2007). Reflecting on the cognitive-social debate in second language acquisition. The Modern Language Journal 91(1), pp. 773-787.

Lasagabaster, D., \& Sierra, J.M. (2005). What do students think about the pros and cons of having a native-speaker teacher? In E. Llurda (Ed.), Nonnative language teachers: Perceptions, challenges and contributions to the profession (pp. 217-242). New York: Springer.

Liang, K. (2002). English as a second language (ESL) students' attitudes towards nonnative English speaking teachers' accentedness (Unpublished master's thesis). California State University, Los Angeles.

Low, E. L. \& Hashim, A. (2012). English in Southeast Asia: Features, policy and language in use. Amsterdam: John Benjamins Publishing.

Mahboob, A. (2003). Status of nonnative Englishspeaking teachers in the United States (Unpublished doctoral dissertation). Indiana University, Bloomington.

Marlina, R. (2014). The pedagogy of English as an International Language (EIL): More reflections and dialogues in Marlina, R. \& Giri, R.A. (Eds.). The pedagogy of English as an International Language: Perspectives from Scholars, teachers, and students. Retrieved on 25-7-2015 from http://www.springer.com/gp/book/9783319061 269

McKay, S.L., \& Brokhorst-Heng, W. (2008). International English in its sociolinguistic contexts: Towards a socially sensitive EIL pedagogy. London: Routledge.

McKay, S.L. (2012). Principles of teaching English as an international language. In L.Alsagoff, S.L. McKay, G. Hu, \& W.A. Renandya (Eds.), Principles and practices for teaching English as an international language (pp. 89-115). Bristol: Multilingual Matters.

Moussu, L. \& Llurda, E. (2008). Non-native English-speaking English language teachers: History and research. Language Teaching, 41(11), pp. 139-147.

Muttaqin, W.M. (2014). English Language teachers towards ASEAN community 2015: Are we ready yet? Paper presented at the international seminar ASEAN Community 2015, Slamet Riyadi University, Surakarta, September. Retrieved on 25-7-2015 from http://www/academia.edu/11017821/English_ Language_Teachers_towards_ASEAN_Comm unity_2015_Are_we_ready_yet/

Pacek, D. (2005). "Personality not nationality": Foreign students' perceptions of a non-native speaker lecturer of English at a British University. In E. Llurda (Ed.), Nonnative language teachers: Perceptions, challenges and contributions to the profession (243-261). New York: Springer.

Philipson, R. (2008). Lingua franca or lingua frankensteinia. World Englishes 27.2, pp. 250267.

Prescott, D. (2007). English in Southeast Asia: Varieties, literacies and literatures. Newcastle, UK: Cambridge Scholars Publishing. 
Saraceni, M. (2009). Relocating English: Towards a new paradigm for English in the world. Language and Intercultural Communication, 9(3), pp. 175-186.

Sharifian, F. (2009). English as an international language: Perspectives and pedagogical issues. Bristol: Multilingual Matters.

Sharifian, F. (2011). Cultural conceptualisations and language. Amsterdam: John Benjamins \& Co.

Walkinshaw, I. \& Duong, O.T.H. (2014). Native and non-native English language teachers: Student perceptions in Vietnam and Japan. SAGE Open, April-June, 1-9.

Wolff, D. (2015). All in the same boat? Native and non-native English speaking teachers' emerging selves in a US MATESOL program. (Unpublished PhD Dissertation) Michigan State University.

Yowono, G.I. \& Harbon, L. (2010). English teacher professionalism and professional development: Some common issues in Indonesia. Asian EFL Journal, 12(3), pp. 141-163

Zacharias, N.T. \& Manara, C. (Eds.). (2013). Contextualizing the pedagogy of English as an international language: Issues and tensions. Newcastle upon Tyne: Cambridge Scholars Publishing.

\section{Interviewees*}

- Aishah A, F, 34, Junior Secondary, Malaysia

- Banoy S, M, 32, Primary, Advanced C1-2, Philippines

- Dian S, M, 48, Junior Secondary, Intermediate $\mathrm{B} 1$, Indonesia

- Gerna E, F, 30, Junior Secondary, Upper Intermediate B2, Philippines

- Hai T, F, 26, Primary, Viet Nam

- Kurnia A, M, 46, Primary, Upper Intermediate B2, Brunei Darussalam

- Madihah A, F, 36, Senior Secondary, Upper Intermediate B2, Brunei Darussalam

- Marla T, F, 43, Senior Secondary, Advanced C12, Myanmar

- Maya L, F, Junior Secondary, Advanced C1-2, Philippines

- Nanda H, F, 46, Junior Secondary, Upper Intermediate B2, Myanmar

- $\mathrm{Nu}$ T, F, 28, University, Viet Nam

- Ollie D, F, Intermediate B1, Cambodia

- Phloi P, F, 52, Senior Secondary, Upper Intermediate B2, Thailand

- Prija B, F, 29, Primary, Intermediate B1, Thailand

- Siti M, F, 36, Secondary, Advanced C1-2, Brunei Darussalam

- Thi W, F, 37, Primary, Advanced C1-2, Myanmar

- Tika H, F, 60, Primary, Upper Intermediate B2, Indonesia

- Zati B, F, 35, Senior Secondary, Intermediate B1, Malaysia

* Interviewees were given a pseudonym to protect their identities. 